\title{
Çoklu Yetersizliğe Sahip Çocuğu Olan Ebeveynlerin Serbest Zaman Etkinliklerine Yönelik Görüşlerinin İncelenmesi
}

\author{
The Opinions of the Parents who have Children with Multiple \\ Disabilities regarding Leisure Time Activities
}

Evgin ÇAY

Emine ERATAY2

\begin{abstract}
Alıntılama: Çay, E. \& Eratay, E. (2019). Çoklu yetersizliğe sahip çocuğu olan ebeveynlerin serbest zaman etkinliklerine yönelik görüşlerinin incelenmesi. Ulusal Ĕgitim Akademisi Dergisi (UEAD), 3(2), 158-184.
\end{abstract}

Geliş tarihi:

25 Teтmuz 2019

Kabul tarihi:

7 Ekim 2019

(C) UEAD 2019

Tüm haklarl saklıdır.

Received:

25 July 2019

Accepted:

7 October 2019
Özet: $\mathrm{Bu}$ çalışmada çoklu yetersizliğe (ÇY) sahip çocuğu olan ebeveynlerin serbest zaman etkinliklerine yönelik görüşlerinin incelenmesi amaçlanmıştır. Araştırmaya ÇY sahip çocuğu olan 10'u kadın, beşi erkek olmak üzere toplam 15 ebeveyn katılmıştır. Araştırma nitel araştırma desenine göre kurgulanmış olup araştırmada yarı yapılandırılmış görüşme tekniği ile veriler toplanmıştır. Görüsşmeler dokuz ile $18 \mathrm{dk}$ arasında sürmüştür. Yapılan görüşmelerden elde edilen veriler betimsel analiz tekniği ile çözümlenmiştir. Araştırma sonucunda; ÇY olan öğrencilerin evde serbest zamanlarında daha çok televizyon izledikleri, kitap okudukları, müzik dinledikleri ve cep telefonuyla oynadıkları tespit edilmiştir. Ebeveynler, evde serbest zamanlarda çocuklarıyla egzersiz yaptıklarını, oyun oynadıklarını, sinemaya ve yemeğe gittiklerini; sohbet ettiklerini, birlikte kitap okuduklarını, dini ibadetlerde bulunduklarını ve seyahat ettiklerini ifade etmişlerdir.

Anahtar kelimeler: çoklu yetersizlik, çoklu yetersizliği olan öğrenci, serbest zaman, serbest zaman etkinliği

Abstract: In this study, it is aimed to examine opinions oft he parents who have children with multiple disabilities regarding leisure time activities. A total of 15 parents, five of whom are male and 10 of whom are female who has children with multiple disbilities, participated in the study. The research was designed according to the qualitative research design and the data were collected by semi-structured interview technique. The interviews lasted between 18 minutes to nine. The data obtained from the interviews were analyzed by descriptive analysis technique. At

\footnotetext{
1 (Sorumlu yazar)Özel Eğit. Bilim Uzm., MEB, evgincay35@gmail.com, ORCID ID:0000-0002-1199-3939.

2 Doç., Abant İzzet Baysal Üniversitesi, erataye@ibu.edu.tr, ORCID ID:0000-0001-6798-1753.
} 
(C) UEAD 2019

All rights reserved. the end of this research, it is concluded that students with multiple disabilities mostly watch television, read books, listen to music and play with mobile phones in their leisure time at home. The parents stated that they were exercising with their children, playing games, going to the cinema and dinner in their leisure time at home; they conversationed, read books together, held religious meetings, and traveled.

Keywords: multiple disabilities, student with multiple disabilities, leisure time, leisure time activity

\section{Giriş}

Alanyazında çoklu yetersizlik (ÇY), birden fazla yetersizliğin bir arada görülme ve yetersizlikten bireylerin etkilenme durumu olarak tanımlanmaktadır. Yani görme, işitme, fiziksel, otizm, zihin vb. yetersizlik türlerinin iki ya da daha fazlasının bir arada görülmesi olarak belirtilebilir (Eldeniz Çetin, 2013; Şafak, 2012). ÇY olan bireyler ise iki ya da daha fazla yetersizlikten etkilenmiş, bu özelliklerinden dolayı da yoğun destek özel eğitime ihtiyacı olan bireylerdir. ÇY olan bireyler etkilendikleri yetersizlik türüne ve derecesine göre sergiledikleri özelliklerle birlikte çeşitli sağlık sorunları (epilepsi, serebral palsi vb.) da yaşayabilmektedirler (Mansell, 2010). Sahip oldukları yetersizlik ve sınırlılıklarından dolayı birçok toplumsal olaylara ve etkinliklere katılımda zorluklar yaşamaktadırlar.

ÇY olan bireylerin toplumda kabul görmesi ve toplum bireyleriyle entegre olabilmesi için içinde yaşadığı toplumsal olay ya da durumlara katılım göstermesi gerekmektedir. Katılım; bireylerin içinde bulunduğu toplum üyelerine ve toplum içindeki olay ya da durumlara eşlik etmesi/ayak uydurması olarak tanımlanmakla (Clark ve Percy-Smith 2006) birlikte bireyin içinde bulunduğu ve katılım gösterdiği alanları ifade etmektedir (WHO, 2001). Bu alanlar; eğitim, aile içi etkinlikler, eğlence vb. sayılabilir ve ÇY olan bireyler bu alanlara katılmada kendi isteğiyle istediği etkinliklere katılmayı seçebilir.

ÇY olan bireyler hayatın her alanında kendi başlarına istediğini seçme hakkına sahip olabilir ve yaşamına dair seçimler yapabilir (Eldeniz Çetin, 2013). Alanyazında seçim yapma, yetersizliği olan bireylerin kendi hayatları adına karar verebilmeleri ve yaşamlarını daha iyi bir hale getirebilmeleri adına önemli görülmektedir (Spevack, Martin, Hiebert, Yu ve Martin, 2004). Dolayısıyla Wehmeyer'e (2003) göre yetersizliği olan bireylerin yaşamlarında önemli bir konuma sahiptir. Bu nedenle, ÇY olan bireylerin çevresinde bulunan bireyler, (aile üyeleri, akran, 
Çay \& Eratay (2019)

öğretmen vb.) ÇY olan bireylere istedikleri serbest zaman alan etkinliklerine katılmalarına olanak sağlayabilir.

Serbest zaman etkinlikleri kavramı ilk önce akla bireyin serbest zamanlarında yaptığı/yapmak istediği etkinlikleri akla getirmektedir. Fakat bunun öncesinde bu etkinliklerin yapıldığı zamanın tanımından ve niteliğinden bahsetmek gerekmektedir. Serbest zaman; bireyin kişisel görev ve sorumluluklarını bir kenara bıraktığı, kendisini geliştirecek ve eğlendirecek etkinliklerle uğraştığı; bu etkinlikleri gerçekleştirirken de haz ve mutluluk duyduğu zaman olarak tanımlanabilir (Cohen-Gewerc ve Stebbins, 2007; Csikzentmihalyi, 2000; Hacıoğlu, Gökdeniz ve Dinç, 2003; Schulz ve Watkins, 2007). Bu zaman diliminde bireylerin kendini mutlu etmek, güzel ve kaliteli bir zaman geçirmek için yaptığı, kendi iradesiyle özgür bir biçimde seçtiği etkinliklerdir (Büküşoğlu ve Bayturan, 2005; Leitner ve Leitner, 2012; Stebbins, 2005; Sivan ve Ruskin, 2000).

Alanyazında serbest zaman etkinlikleri, ciddi ve kayitsız serbest zaman etkinlikleri olarak sinıflandırılmaktadır (Cohen-Gewerc ve Stebbins, 2007). Ciddi serbest zaman etkinlikleri; bireylerin ilgi ve yetenekleri doğrultusunda herhangi bir alanda bilgi, beceri kazanmak için yapılan ayrica yapılırken bireye mutluluk ve haz veren profesyonel anlamda ilgilenmeyi gerektiren etkinliklerdir. Kayıtsız serbest zaman etkinlikleri ise; bireyin sadece dinlenmek ve eğlenmek için yaptığı herhangi bir yetenek gerektirmeyen etkinliklerdir. Örnek verilecek olursa, televizyon izlemek, kitap okumak, radyo dinlemek, dans etmek vb. etkinliklerdir (Akyıldız, 2013).

ÇY olan bireyler çeşitli serbest zaman etkinlikleriyle serbest zamanlarını verimli ve kaliteli bir şekilde geçirebilirler. Dans, drama, müzik, el becerileri gerektiren etkinliklere katılarak hem güzel vakit geçirebilir hem de ortamda bulunan bireylerle etkileşimde bulunabilir. $\mathrm{Bu}$ tür etkinliklere uyum sürecinde ÇY olan bireylerin kimi daha az yardıma ihtiyaç duyarken kimi ise daha çok yardıma ihtiyaç duyabilir (Mount, 2013). Ouvry ve Mitchell'e (2013) göre oyun ve oyuncaklar da ÇY olan bireyler için serbest zaman değerlendirme etkinliklerinden biridir. 


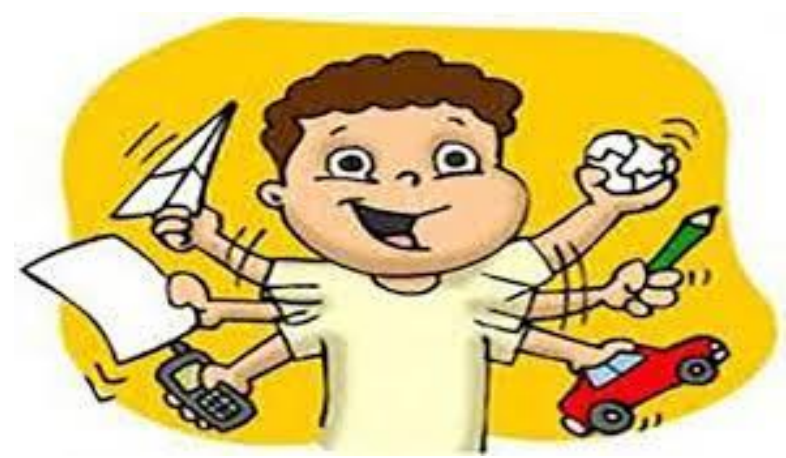

Resim 1. Oyun Etkinlikleri ve Oyuncaklar (rehberlikburada.com)

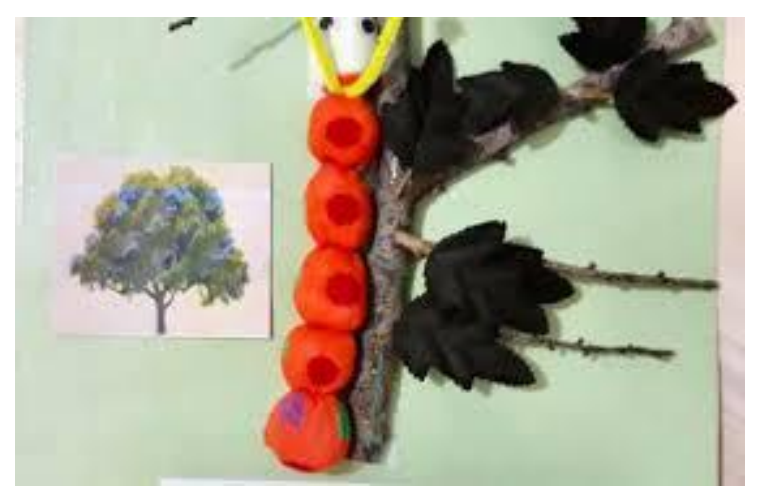

Resim 2. El Becerileri Gerektiren Etkinlikler (cokengelsiz.com)

ÇY olan bireylerin yapabilecekleri başka bir etkinlik alanı ise fiziksel etkinlik alanlarıdır. Bireyler; aileleri eşliğinde doğa yürüyüşleri yapabilir, spor salonlarında ya da ev ortamında egzersiz hareketleri yaparak hem fiziksel açıdan hem de sosyal açıdan bu etkinlik türünden faydalanmış olurlar. Gerçekleştirilen fiziksel etkinlikler, bireylerin zinde olmasını sağlayarak bireyin öz yeterlik algısını geliştirmede ve kendini iyi hissetmesine yardım eder (Badia, Orgaz, Verdugo, Ullán, ve Martinez, 2013). Fakat bu tür bireylerin spor ve fiziksel etkinlikleri yapabilmeleri için motivasyona ve desteğe ihtiyaç duyabilirler. Hatta spor merkezlerinden faydalanabilmeleri için çeşitli düzenlemelere ihtiyaç duyabilirler (Leach ve Bailey, 2013).

ÇY olan bireyler, aile üyeleriyle birlikte çeşitli tatil ve gezilere katılarak serbest zamanlarını aile üyeleriyle birlikte kaliteli bir şekilde geçirebilirler. Aile bireyleriyle yapılan tatil ve geziler de bireyi eğlendiren, mutlu eden serbest zaman etkinlikleri arasında sayılabilir. ÇY olan bireylerin bu tür etkinlikleri yapmaya vakitleri olmakla birlikte kimi zaman ulaşım ve maddi olanaksızlıklar sebebiyle kısıtlılık yaşabilmektedirler (Lambe ve Mount, 2013). ÇY olan bireylerin yapmaktan hoşlandığı ve serbest zamanlarını değerlendirebileceği etkinliklerden bir 
Çay \& Eratay (2019)

tanesi de ailesi eşliğinde yapabileceği bahçe işleridir. Bahçede çiçek sulama ve gübreleme, ekme, dikme etkinlikleriyle ilgilenebilirler. ÇY olan bireyler bahçe etkinliklerine katılmak da sınırlılık gösterseler de bu tür etkinlikleri yapmaktan zevk alabilirler (Lambe ve Mount, 2013). Fakat ÇY olan bireyler bu tür serbest zaman etkinliklerine ya daha az katılım göstermekte ya da sınırlı bir şekilde aile bireyleriyle katılabilmektedirler. Genellikle serbest zamanlarını ve bu zaman diliminde gerçekleştirdikleri etkinlikleri aileleriyle yapmaktadırlar (Engel-Yeger, Jarus, Anaby, Law, 2009; Eriksson, Welander, Granlund, 2007; Solish, Perry, Minnes, 2010).

Serbest zaman etkinlikleri yetersizliği olan bireylerin tıpkı eğitim, sağlık gibi temel ihtiyaç ve haklarından biridir. Üstelik bu tür bireylerin yaşam standartlarını ve kalitesini arttırdığı için bir firsat olarak görülebilir. Yaşam içerisinde bireyler birçok stres, olumsuz duygular ve düşünceler yaşayabilir ve bu bireylerin yaşamını olumsuz etkiler. Bu tür olumsuzlukların azaltılması ve giderilmesinde serbest zaman etkinlikleri yardımcı olabilir (Sivan ve Ruskin, 2000). Ayrıca serbest zaman etkinlikleri bireylerin çevresiyle iletişim kurması, akranlarıyla etkileşimde bulunması, özgüven kazanmaları gibi sosyal açıdan da faydalar sağlamaktadır. Yapılan çalışmaların (Devine, 2016; Gilson ve Dymond, 2011; Lundberg, Taniguchi, McCormick, ve Tibbs, 2011; Jessup, Cornell, ve Bundy, 2010; Porter, Iwasaki, ve Shank, 2010) bulguları da bu yöndedir. 


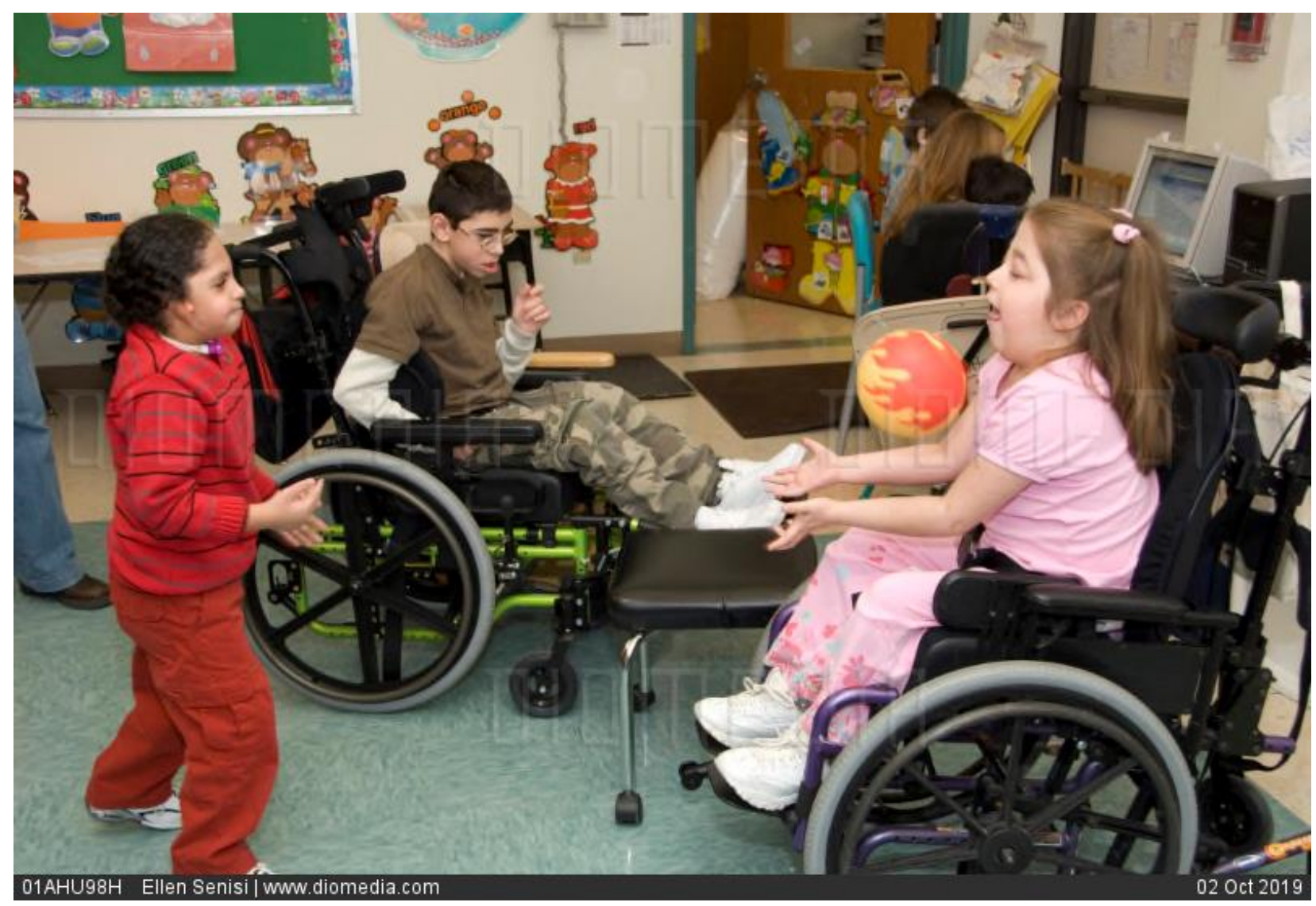

Resim 3. ÇYE Olan Bireylerin Akranlarıyla Birlikte Olduğu Etkinlikler (www.diomedia.com)

İlgili literatürde serbest zaman etkinliklerine yönelik çalışmaların (Bayram, 2016; Büküşoğlu ve Bayturan, 2005; Devine, 2016; Eldeniz Çetin ve Çay, 2017; Eratay, 2013; Eratay ve Aydoğan, 2015; Gilson ve Dymond, 2012; Lundberg, Taniguchi, McCormick, ve Tibbs, 2011; Jessup, Cornell, ve Bundy, 2010; Porter, Iwasaki, ve Shank, 2010; Trainor, Dellfabbro, Anderson, Winefield, 2009) yapıldığı görülmektedir. Ayrıca yetersizliği olan bireylerin serbest zaman etkinliklerinden olan fiziksel etkinliklere katılım durumlarını etkileyen durumları belirlemeye yönelik yapılmış çalışmalar (Güngörmüş, 2007; Gümüş, Iş1k, Karakullukçu ve Yıldırım, 2016; Kim, Lee, Chun, Heo ve Han 2014; Müderrisoğlu, Kutay ve Örnekci Eşen, 2006) da bulunmakla birlikte ağır ve çoklu yetersizliği olan bireylerle ilgili ulusal alanyazında oldukça az sayıda çalışma yer almaktadır. Bununla birlikte Ulusal alanyazında ÇY olan bireylerin ebeveynlerinin çeşitli konular hakkında görüşlerine yer veren çalışmalar (Akandere, Acar ve Baştuğ, 2009; Bahçıvancıoğlu Yazıcı ve Akçin, 2014; Eldeniz Çetin, 2013; Sardohan Yıldırım ve Akçamete, 2014; Şafak ve Uyar, 2015) da mevcuttur. Ağır düzeyde yetersizliğe sahip çocuğu 
Çay \& Eratay (2019)

olan annelerin çocuklarının boş zamanlarını değerlendirmelerine yönelik görüşlerini belirleyen sadece bir araştırmaya (Eldeniz Çetin ve Terzioğlu, 2018) ulaşılmıştır. Sözü edilen çalışmada ağır düzeyde yetersizliğe sahip çocuğu olan annelerin görüşleri belirlenmiştir. Yapılan çalışmada ise; ÇY olan bireylerin serbest zamanlarında yaptıkları etkinliklerin hem anne hem de babaların görüşlerine göre incelenmiştir. ÇY olan bireyler zamanlarının çoğunu genelde anneleriyle vakit geçirmekte, babalar herhangi bir meslek dalında çalıştığı için çocuklarına pek vakit ayıramadığı/ayırmadığı söylenebilir. Bu yüzden ÇY olan çocuklarına zaman ayıran anne ve özellikle de babaların çocuklarıyla nasıl vakit geçirdikleri, ayırdıkları zaman içerisinde hangi serbest zaman etkinliklerini yaptıklarını belirlemek önemli görülmektedir. Dolayısıyla ÇY olan bireylerin serbest zamanlarında yaptıkları etkinlikleri hem anne hem de babaların görüşlerine göre inceleyen herhangi bir araştırmaya ulaşılamamıştır. ÇY olan bireylerin serbest zamanlarını kendi başlarına ya da aile üyeleriyle birlikte kaliteli bir şekilde geçirmesi; bireyi sosyal, fiziksel ve zihinsel açıdan geliştirmesi ve bu tür bireylere bir şeyler katmasi; etkinlikleri gerçekleştirirken aynı zamanda eğlenerek kişisel gelişimine katkıda bulunması önemli görülmektedir. ÇY çocuğa sahip ebeveynlere çocuklarıyla birlikte ne tür etkinlikler yapabilecekleri, çocuklarıyla serbest zamanlarını kaliteli bir şekilde geçirmelerine yönelik fikir vereceği düşünüldüğünden yapılan araştırmanın ebeveynlere katkı sunacağı öngörülmektedir. ilgili alanyazına dolayısıyla ÇY sahip çocuğu olan ebeveynlerin serbest zaman etkinliklerine yönelik görüşlerini incelemek ve belirlemek bu araştırmanın amacını oluşturmaktadır.

\section{Araştırmanın amacı}

$\mathrm{Bu}$ araştırmanın genel amacı; ÇY sahip çocuğu olan ebeveynlerin serbest zaman etkinliklerine yönelik görüşlerini incelemektir. Bu genel amaç doğrultusunda aşağıda yer alan sorulara yanıt aranmıştır:

1) ÇY olan öğrenciler serbest zamanlarında ev ortamında ne tür serbest zaman etkinlikleri yapmaktadırlar?

2) ÇY olan öğrenciler ebeveynleri ile ne tür serbest zaman etkinlikleri yapmaktadırlar?

3) ÇY olan öğrencilerin aile üyeleriyle yapmaktan hoşlandığı serbest zaman etkinlikleri nelerdir?

4) Ebeveynlerin serbest zamanlarda çocuklarının yapmasını istediği etkinler nelerdir?

\section{Yöntem}


Çoklu Yetersizliğe Sahip Çocuğu Olan Ebeveynlerin Serbest Zaman Etkinliklerine

Yönelik Görüşlerinin İncelenmesi

$\mathrm{Bu}$ bölümde araştırmanın modeline, katılımcılara, verilerin toplanmasına ve verilerin analizine yer verilmektedir.

\section{Araştırma Modeli}

$\mathrm{Bu}$ araştırmada nitel araştırma yöntemlerinden belli bir durumu veya bir olayı ortaya çıkarmak (Yıldırım ve Şimşek, 2008) için kullanılan tipik durum çalışması yöntemi kullanılmıştır. Nitel araştırma yöntemlerinden yarı-yapılandırılmış görüşme tekniği kullanılarak veriler toplanmıştır. Araştırmada ÇY olan öğrencilerin serbest zamanlarda yaptıkları etkinlikleri belirlemek için bu desen kullanılmıştır.

\section{Katılımcılar}

Araştırmanın katılımcılarını özel eğitim meslek okulunda öğrenimine devam eden öğrencilerin ebeveynleri oluşturmaktadır. Araştırmada ölçüt örnekleme tekniği kullanılarak katılımcılar belirlenmiştir. Belirlenen ölçütler ise; çocuklarında zihin yetersizliğine eşlik eden ek bir yetersizliğinin olması, çocuklarının yaşlarının 15-18 arasında olmasıdır. Bu kriterleri karşılayan 15 ebeveyn araştırmanın katılımcılarını oluşturmuştur. Araştırmaya katılan ebeveynlere ilişkin demografik bilgilere Tablo1'de yer verilmiştir.

Tablo 1. Katılımcıların Demografik Bilgileri

\begin{tabular}{|c|c|c|c|c|c|c|}
\hline Kod Adı & $\begin{array}{l}\text { Ebeveynin } \\
\text { Yaş }\end{array}$ & $\begin{array}{l}\text { Ebeveynin } \\
\text { Cinsiyet }\end{array}$ & $\begin{array}{l}\text { Ebeveynin } \\
\text { Eğitim } \\
\text { Düzeyi }\end{array}$ & $\begin{array}{l}\text { ÇY Olan } \\
\text { Bireyin Yaşı }\end{array}$ & $\begin{array}{l}\text { ÇY Olan } \\
\text { Bireyin } \\
\text { Yetersizlik } \\
\text { Türü ve } \\
\text { Şiddeti }\end{array}$ & $\begin{array}{l}\text { ÇY Olan } \\
\text { Bireye } \\
\text { Yakınlık } \\
\text { Derecesi }\end{array}$ \\
\hline E.1 & 35 & $\mathrm{~K}$ & İlkokul & 15 & $\begin{array}{l}\text { Hafif düzey } \\
\text { zihinsel } \\
\text { yetersizlik ve } \\
\text { otizm }\end{array}$ & Annesi \\
\hline E.2 & 40 & $\mathrm{E}$ & Ortaokul & 15 & $\begin{array}{l}\text { Hafif düzey } \\
\text { zihinsel } \\
\text { yetersizlik ve } \\
\text { hafif düzey } \\
\text { işitme } \\
\text { yetersizliği }\end{array}$ & Babası \\
\hline E.3 & 41 & $\mathrm{E}$ & Lise & 18 & $\begin{array}{l}\text { Hafif düzey } \\
\text { zihinsel } \\
\text { yetersizlik ve } \\
\text { hafif düzey } \\
\text { işitme } \\
\text { yetersizliği }\end{array}$ & Babası \\
\hline E.4 & 49 & $\mathrm{~K}$ & İlkokul & 16 & $\begin{array}{l}\text { Hafif düzey } \\
\text { zihinsel } \\
\text { yetersizlik ve }\end{array}$ & Annesi \\
\hline
\end{tabular}


Çay \& Eratay (2019)

\begin{tabular}{|c|c|c|c|c|c|c|}
\hline & & & & & $\begin{array}{l}\text { serebral palsi } \\
\text { (dipleji) }\end{array}$ & \\
\hline E.5 & 38 & $\mathrm{~K}$ & İlkokul & 15 & $\begin{array}{l}\text { Hafif düzey } \\
\text { zihinsel } \\
\text { yetersizlik ve } \\
\text { konuşma } \\
\text { güçlüğü }\end{array}$ & Annesi \\
\hline E.6 & 35 & $\mathrm{~K}$ & Ortaokul & 16 & $\begin{array}{l}\text { Hafif düzey } \\
\text { zihinsel } \\
\text { yetersizlik ve } \\
\text { serebral palsi } \\
\text { (dipleji) }\end{array}$ & Annesi \\
\hline E.7 & 41 & $\mathrm{~K}$ & Ortaokul & 16 & $\begin{array}{l}\text { Hafif düzey } \\
\text { zihinsel } \\
\text { yetersizlik ve } \\
\text { hafif düzey } \\
\text { işitme } \\
\text { yetersizliği }\end{array}$ & Annesi \\
\hline E. 8 & 36 & $\mathrm{E}$ & İlkokul & 17 & $\begin{array}{l}\text { Hafif düzey } \\
\text { zihinsel } \\
\text { yetersizlik ve } \\
\text { hafif düzey } \\
\text { işitme } \\
\text { yetersizliği }\end{array}$ & Babası \\
\hline E.9 & 32 & $\mathrm{~K}$ & Ortaokul & 17 & $\begin{array}{l}\text { Hafif düzey } \\
\text { zihinsel } \\
\text { yetersizlik ve } \\
\text { konuşma } \\
\text { güçlüğü }\end{array}$ & Annesi \\
\hline E.10 & 37 & $\mathrm{~K}$ & İlkokul & 18 & $\begin{array}{l}\text { Hafif düzey } \\
\text { zihinsel } \\
\text { yetersizlik ve } \\
\text { serebral palsi } \\
\text { (hemipleji) }\end{array}$ & Annesi \\
\hline E.11 & 37 & $\mathrm{~K}$ & Lise & 16 & $\begin{array}{l}\text { Hafif düzey } \\
\text { zihinsel } \\
\text { yetersizlik ve } \\
\text { hafif düzey } \\
\text { işitme } \\
\text { yetersizliği }\end{array}$ & Annesi \\
\hline E.12 & 43 & $\mathrm{E}$ & İlkokul & 18 & $\begin{array}{l}\text { Hafif düzey } \\
\text { zihinsel } \\
\text { yetersizlik ve } \\
\text { serebral palsi } \\
\text { (dipleji) }\end{array}$ & Babası \\
\hline E.13 & 40 & $\mathrm{E}$ & Lise & 18 & $\begin{array}{l}\text { Hafif düzey } \\
\text { zihinsel } \\
\text { yetersizlik ve } \\
\text { serebral palsi } \\
\text { (dipleji) }\end{array}$ & Babas1 \\
\hline E.14 & 35 & $\mathrm{~K}$ & Ortaokul & 16 & $\begin{array}{l}\text { Hafif düzey } \\
\text { zihinsel } \\
\text { yetersizlik ve } \\
\text { serebral palsi }\end{array}$ & Annesi \\
\hline
\end{tabular}


Çoklu Yetersizliğe Sahip Çocuğu Olan Ebeveynlerin Serbest Zaman Etkinliklerine Yönelik Görüşlerinin İncelenmesi

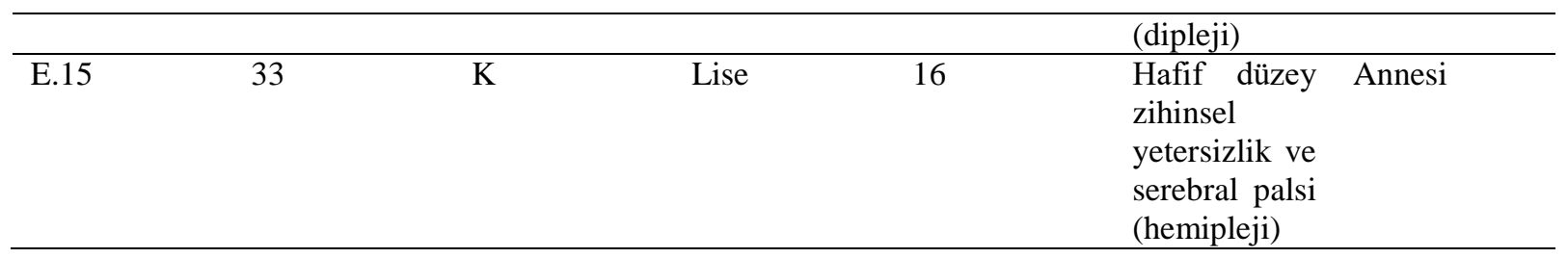

Tablo 1 incelendiğinde; ebeveynlerden altısı ilkokul, beşi ortaokul ve dördü ise lise mezunudur. 10’u kadın, beşi erkek olan ebeveynlerin yaşları 33 ile 49 yaş aralığında değişmektedir. Araştırmaya katılan ebeveynlerin çocuklarının yaşları ise 15 ile 18 yaş arasında değişkenlik göstermektedir. Ebeveynlerden altısı ilkokul, beşi ortaokul ve dördü de lise mezunudur. Çocukların biri zihin yetersizliğine ek hafif düzeyde otizm, beşi zihin yetersizliğine ek hafif düzeyde işitme yetersizliği, yedisi zihin yetersizliğine ek serebral palsi, ikisi zihin yetersizliğine ek konuşma güçlüğüne sahiptir. Araştırmaya gönüllü olarak ÇY sahip çocuğu olan 10 anne ve ÇY çocuğa sahip beş baba katılmıştır.

\section{Verilerin Toplanması}

$\mathrm{Bu}$ araştırmada ÇY sahip bireylerin serbest zamanlarında yaptıkları etkinlikleri ebeveyn görüşlerine göre belirlemek için aşağıda yer alan sorular araştırmaya gönüllü olarak katılan ebeveynlere sorulmuştur. Görüşmelerde ebeveynlere yöneltilen sorular şu şekildedir:

1. Çocuğunuz evde serbest zamanlarında neler yapar? Anlatır mısınız?

2. Çocuğunuzla yaptığınız serbest zaman etkinlikleri nelerdir?
a) Fiziksel etkinlikler (beden olarak güç gerektiren)
b) Sosyal etkinlikler
c) Yetenek gerektiren etkinlikler
d) Kişisel gelişim etkinlikleri

3. Çocuğunuzun sizinle yapmaktan hoşlandığı serbest zaman etkinlikleri nelerdir, anlatır misiniz?
a) Annesiyle yapmaktan hoşlandığı etkinlikler
b) Babasıyla yapmaktan hoşlandı̆̆ı etkinlikler
c) Varsa kardeşiyle (abi-abla) yapmaktan hoşlandığg etkinlikler

4. Çocuğunuzun serbest zamanlarında yapmasını istediğiniz etkinlikler nelerdir? 
Araştırma verilerini toplamak için araştırmacılar tarafından alan yazın taranarak hazırlanan görüşme formu, özel eğitim alanında ve ölçme değerlendirme alanında çalışan alan uzmanlarının görüşleri alınarak son hali verilmiştir. Yarı yapılandırılmış görüşme tekniğine uygun hazırlanan görüşme soruları çocuğu ÇY olan ebeveynlere bire bir sorularak görüşleri kayıt altına alınmıştır. Görüşmeye başlamadan önce görüşmenin amacı açıklanmış, yapılan görüşmelerin başka hiçbir yerde yayınlanmayacağı belirtilerek katılımcılardan görüşmeler için yazılı izin alınmıştır. Araştırmacı kendini tanıtmış, görüşmenin amacını açıklayarak kaydın nasıl yapılacağını açıklamıştır. Görüşme başladığı andan itibaren ses kaydı açılarak veriler toplanmıştır. Görüşmeler çocukların öğrenim gördüğü özel eğitim okulunda yapılmıştır. Görüşmeler yaklaşık dokuz ile 18 dakika arasında sürmüştür. Yapılan görüşmelerin toplam süresi ise 254 dakikadır.

\section{Geçerlik ve Güvenirlik}

Nitel araştırmalarda geçerlik ve güvenirlik çalışmaları 'inandırıcılık, aktarılabilirlik ve teyit edilebilirlik' kavramlarıyla belirtilmektedir (Yıldırım ve Şimşek, 2008). Yapılan araştırmada inandırıcılığı sağlamak adına görüşme formunda yer alan sorular, araştırma sonunda elde edilen veriler ve bu verilere ilişkin yapılan yorumlar özel eğitim ve ölçme değerlendirme alanında uzmanların görüşlerine sunularak uzman görüşleri alınmıştır. Ayrıca inandırıcılığı sağlamak adına yapılan başka bir adım ise; araştırma sonunda elde edilen bulgular araştırmaya katılmaya gönüllü olan katılımcıların \%25'ine (3 ebeveyn) gösterilerek katılımcı onayı alınmıştır. Araştırmanın dış geçerliğine ilişkin, katılımcıların araştırmaya ilişkin ifade ettikleri tırnak içerisinde aynen aktarılarak verilmiştir.

Aktarılabilirliği sağlamak için ise araştırmada elde edilen ham veriler ile verilere ilişkin sonuçlar ve bu verilere ilişkin yapılan yorumlar için alan uzmanının onayı alınmıştır ayrıca görüşmelerin yapıldığ nasıl seçildikleri belirtilmiştir. Yapılan araştırmada onaylanabilirliği/teyit edilebilirliği sağlamak adına alan yazın taraması yapılarak genel amacı yansıtacak şekilde görüşme soruları hazırlanmıştır. Çalışmanın genel amacı açıklanmış, hazırlanan sorulara verilen cevaplar yazılı hale getirilmiştir.

\section{Verilerin Analizi}

ÇY olan öğrencilerin serbest zamanlarda yaptıkları etkinliklerin ebeveyn görüşlerine göre incelemek için hazırlanan sorulara vermiş oldukları cevaplar yazılı hale getirilmiştir. Yapılan deşifre işleminin güvenirliği dökümanların $\% 30$ unda yapılmış ve $\% 100$ olarak hesaplanmıştır. 
Çoklu Yetersizliğe Sahip Çocuğu Olan Ebeveynlerin Serbest Zaman Etkinliklerine

Bilgisayar ortamına aktarılan veriler araştırma soruları tema kabul edilerek betimsel analiz yöntemi ile söylenme sıklığı dikkate alınarak analiz edilmiştir. Araştırmada görüşmecilerin beyan ettikleri, E1, E2 gibi kodlarla aynen söyledikleri şekilde tırnak içinde aktarılmıştır. Analiz sürecinde iki aşama izlenmiştir.

\section{Elde edilen verilerin deşifre edilmesi}

Araştırmacılar tarafından yapılan görüşmeler deşifre edilmiştir. Görüşmelerdeki ses kayıtlarından toplam 25 Word sayfası elde edilmiştir.

\section{Elde edilen verilerin analiz süreci}

> Görüşmelerdeki ebeveynleri kodlamak için E1,2,3 gibi kodlamalar yapılmıştır.

$>$ Aynı soruyla ilgili ebeveynlerin cevapları gruplanmıştır.

> Her soruya verilen cevaplar birkaç kez okunmuştur.

> Sorular tema kabul edilerek bu temalar çerçevesinde kodlamalar yapılmıştır.

$>$ Kodların ebeveynler tarafından söylenme sıklıkları hesaplanarak frekans olarak raporlaştırılmış ve öğretmenlerin kendi ifadeleri ile alıntılamalar yapılmıştır.

\section{Bulgular}

$\mathrm{Bu}$ bölümde ÇY olan öğrencilerin serbest zamanlarda yaptıkları etkinlikleri ebeveyn görüşlerine göre belirlemek için yapılan görüşmelerden elde edilen bulgulara yer verilmiştir.. Araştırmada kullanılan sorular tema olarak belirlenip söylenme sıklı̆̆ı (frekans) 'f' dikkate alınarak tablolar oluşturulmuştur. Elde edilen bulgular sorulara göre sıralanarak verilmiştir.

ÇY olan çocukların evde serbest zamanlarda yaptıkları etkinliklere yönelik ebeveynlerin ifadelerini kapsayan bulgular

ÇY sahip çocuğu olan ebeveynlerin "Çocuğunuz evde serbest zamanlarında neler yapar? Anlatır mısınız?', sorusuna verdiği yanıtlar Tablo1'de yer almaktadır.

Tablo 1. ÇY Olan Çocukların Evde Serbest Zamanlarda Yaptıkları Etkinliklere Yönelik Ebeveynlerin Ífadelerini Kapsayan Bulgular

\begin{tabular}{lc}
\hline Cevaplar & f \\
\hline Tv izler & 11 \\
\hline Kitap okur & 4 \\
\hline
\end{tabular}


Çay \& Eratay (2019)

\begin{tabular}{lc}
\hline Müzik dinler & 4 \\
\hline Ödev yapar & 4 \\
\hline Cep telefonuyla oynar & 2 \\
\hline Kardeşiyle oyun oynar & 2 \\
\hline Kardeşiyle sohbet eder & 2 \\
\hline Boyama yapar & 2 \\
\hline Kendince deney yapar & 2 \\
\hline Kağit keser & 2 \\
\hline Egzersiz yapar & 2 \\
\hline Dans eder & 2 \\
\hline Muhabbet kuşuyla oynar & 2 \\
\hline Tabletle oynar & 2 \\
\hline Dinlenir & 1 \\
\hline Resim yapar & 2 \\
\hline
\end{tabular}

Tablo 1 incelendiğinde ebeveynler, çocuklarının serbest zamanlarda tv izlediğini, müzik dinlediğini, kitap okuduğunu, ödevlerini yaptığını, cep telefonuyla oynadığını, kardeşiyle oyunlar oynadığını, boyama yaptığını, deney yaptığını, kağıt kestiğini, egzersizlerini yaptığını, dans ettiğini, muhabbet kuşuyla vakit geçirdiğini, tabletle oyunlar oynadığını, dinlendiğini ve resim yaptığını belirtmişlerdir. ÇY sahip çocuğu olan ebeveynlerin söyledikleri aşağıda tırnak içinde aynen aktarılmıştır.

E1. 'daha çok televizyon izliyor. Sevdiği programları izlemeyi çok seviyor"'

E5. "kardeşiyle dans eder, kardeşi pek onunla dans etmek istemese de",

E9. "okulda ögretmenin verdiği ödevleri yapıyor"

ÇY sahip çocuğu olan ebeveynlerin, çocuklarıyla yaptıkları serbest zaman etkinliklerine yönelik ifadelerini kapsayan bulgular

ÇY sahip çocuğu olan ebeveynlerin “'Çocuğunuzla yaptığınız serbest zaman etkinlikleri nelerdir?' sorusuna verdiği cevaplar Tablo 2'de verilmiştir.

Tablo 2. ÇY Sahip Çocuğu Olan Ebeveynlerin, Çocuklarıla Yaptıkları Serbest Zaman Etkinliklerine Yönelik Ifadelerini Kapsayan Bulgular

Cevaplar


Çoklu Yetersizliğe Sahip Çocuğu Olan Ebeveynlerin Serbest Zaman Etkinliklerine Yönelik Görüşlerinin İncelenmesi

\begin{tabular}{ll}
\hline Fiziksel etkinlikler & 9 \\
\hline Egzersiz yapmak & 6 \\
\hline Oyun oynamak & 5 \\
\hline Bahçede zaman geçirmek & 4 \\
\hline Seyahat etmek & $\mathbf{f}$ \\
\hline Sosyal etkinlikler & 10 \\
\hline Sinemaya gitmek & 4 \\
\hline Arkadaşlarıyla buluşmak & 2 \\
\hline Yemeğe gitmek/çımak & 2 \\
\hline Sohbet etmek & $\mathbf{f}$ \\
\hline Yetenek gerektiren etkinlikler & 9 \\
\hline Resim yapmak & 5 \\
\hline Yüzmeye gitmek & 2 \\
\hline Müzik dinlemek & 2 \\
\hline Ahşap boyama yapmak & 2 \\
\hline Yazı yazmak & 1 \\
\hline Dans etmek & $\mathbf{f}$ \\
\hline Kişisel gelişim etkinlikleri & 8 \\
\hline Ödev yapmak & 6 \\
\hline Kitap okumak & 5 \\
\hline Dini ibadetlerde bulunmak & 2 \\
\hline Şiir okumak & 1 \\
\hline Kişisel bir becerisi yok & 2 \\
\hline
\end{tabular}

Tablo 2 incelendiğinde ÇY sahip çocuğu olan ebeveynler, çocuklarıyla yaptıkları fiziksel etkinliklere yönelik; egzersiz yaptıkları, oyun oynadıkları, bahçede vakit geçirdikleri, seyahat ettiklerini, sosyal etkinliklere yönelik; sinemaya gittikleri, arkadaşlarıyla buluştukları, yemeğe çıktıkları ve sohbet ettiklerini, yetenek gerektiren etkinliklere yönelik; resim yaptıkları, yüzmeye gittikleri, müzik dinledikleri, ahşap boyama yaptıkları, yazı yazdıkları ve dans ettiklerini, kişisel gelişim etkinliklerine yönelik ise; ödev yaptıkları, birlikte kitap okudukları, dini ibadetlerde bulundukları, şarkı söyledikleri, şiir okuduklarını ifade etmişlerdir. Bir ebeveyn ise çocuğunun herhangi bir kişisel becerisinin olmadığını belirtmiştir. ÇY sahip çocuğu olan ebeveynlerin söyledikleri aşağıda tırnak içinde aynen aktarılmıştır. 
Çay \& Eratay (2019)

E6. "onun sevdiği kitaplart seçip beraber okuyoruz"

E8. "günlük egzersizlerini yapıyoruz"'

E2. "sevdiği filmleri beraber izlemeyi seviyoruz",

ÇY olan öğrencilerin aile üyeleriyle yapmaktan hoşlandığı serbest zaman etkinliklerine yönelik bulgular

Ebeveynlerin "Çocuğunuzun sizinle yapmaktan hoşlandığı serbest zaman etkinlikleri nelerdir, anlatır mısınız?" sorusuna verdiği cevaplar Tablo 3'te verilmiş̧tir.

Tablo 3. ÇY Olan Öğrencilerin Aile Üyeleriyle Yapmaktan Hoşlandı̆̆̆ Serbest Zaman Etkinliklerine Yönelik Bulgular

\begin{tabular}{|c|c|}
\hline Cevaplar & f \\
\hline \multicolumn{2}{|l|}{ Annesiyle yapmaktan hoşlandığı etkinlikler } \\
\hline Ev işi yapmak & 3 \\
\hline Alış veriş etmek & 3 \\
\hline Seyahat etmek & 3 \\
\hline Boyama ve resim yapmak & 2 \\
\hline Kahve içmek & 2 \\
\hline Anneyle kitap okumak & 2 \\
\hline Film seyretmek & 2 \\
\hline Sohbet etmek & 1 \\
\hline Sinemaya gitmek & 1 \\
\hline Babasıyla yapmaktan hoşlandığı etkinlikler & $\mathbf{f}$ \\
\hline Gezmek & 7 \\
\hline Sohbet etmek & 6 \\
\hline Seyahat etmek & 6 \\
\hline Ders yapmak & 5 \\
\hline Oyun oynamak & 5 \\
\hline Yürüyüş yapmak & 5 \\
\hline Maça gitmek & 4 \\
\hline Pikniğe gitmek & 4 \\
\hline Sinemaya gitmek & 2 \\
\hline Varsa kardeşiyle (abi-abla) yapmaktan hoşlandığı etkinlikler & $\mathbf{f}$ \\
\hline Oyun oynamak & 9 \\
\hline Film izlemek & 3 \\
\hline Doğada zaman geçirmek & 2 \\
\hline
\end{tabular}


Çoklu Yetersizliğe Sahip Çocuğu Olan Ebeveynlerin Serbest Zaman Etkinliklerine Yönelik Görüşlerinin İncelenmesi

\begin{tabular}{lc}
\hline Yemek yemek & 2 \\
\hline Sohbet etmek & 2 \\
\hline Resim yapmak & 2 \\
\hline Ders yapmak & 2 \\
\hline
\end{tabular}

Tablo 3 incelendiğinde ebeveynler, çocukların anneleriyle ev işi yapmak, alışveriş etmek, seyahat etmek, boyama ve resim yapmak, kahve içmek, kitap okumak, film seyretmek, sohbet etmek ve sinemaya gitmek olduğunu, babalarıyla; gezmek, sohbet etmek, seyahat etmek, ders yapmak, oyun oynamak, yürüyüş yapmak, maça gitmek, pikniğe gitmek ve sinemaya gitmek, ağabeyi ya da ablasıyla ise; oyun oynamak, film izlemek, doğada zaman geçirmek, yemek yemek, sohbet etmek, resim yapmak ve derslerini yapmak olduğunu ifade etmişlerdir. ÇY sahip çocuğu olan ebeveynlerin söyledikleri aşağıda tırnak içinde aynen aktarılmıştır.

E4. “ev işlerinde bana yardım etmeyi seviyo",

E7. " ara ara dişarlya ev gezmelerine gidiyoruz”,

E9. "kahve içip sohbet ediyoz",

E10. "babasıyla dışarıya çıkıp gezmeyi seviyo"

E6. ' "akşam yemekten sonra babasiyla sohbet ediyolar'”

E8. "okulda verilen etkinlikleri babasıly evde yapıyorlar"'

E1. " abisiyle oyunlar oynamayl seviyor",

E5. "kardeşiyle sevdiği çizgi filmleri izlemeyi çok seviyo”,

E9. " ablasıyla resim yapmaktan hoşlanıyor"”

Ebeveynlerin, serbest zamanlarda çocuklarının yapmasını istediği etkinliklere yönelik ifadelerini kapsayan bulgular

Ebeveynlerin, "Çocuğunuzun serbest zamanlarında yapmasını istediğiniz etkinlikler nelerdir?' sorusuna verdiği cevaplar Tablo 4'te verilmiştir.

Tablo 4. Ebeveynlerin, Serbest Zamanlarda Çocuklarının Yapmasını Istediği Etkinliklere Yönelik Ifadelerini Kapsayan Bulgular

\begin{tabular}{lc}
\hline Cevaplar & f \\
\hline Kitap okuması & 7 \\
\hline Fiziksel hareket yapması & 4 \\
\hline Akademik etkinlikler & 4 \\
\hline
\end{tabular}


Çay \& Eratay (2019)

\begin{tabular}{lc}
\hline Yemek yapmasını & 4 \\
\hline El ve kol kaslarını geliştiren etkinlikler & 4 \\
\hline Kendisini geliştirebileceği her şey & 3 \\
\hline Boyama yapma & 3 \\
\hline Spor & 3 \\
\hline Kağıt kesme & 1 \\
\hline İbadet etmesi & 1 \\
\hline Annesine yardım etmesi & 1
\end{tabular}

Tablo 4 incelendiğinde ebeveynler; serbest zamanlarda çocuklarının kitap okuması, fiziksel hareket yapması, akademik etkinlikler yapması, yemek yapması, el ve kol kaslarını geliştiren etkinlikler yapması, kendisini geliştirebilecek etkinlikler, boyama yapması, kağıt kesme etkinlikleri yapma, spor, ibadet etmesi ve annesine yardım etmesini istediklerine yönelik görüş bildirmişlerdir. ÇY sahip çocuğu olan ebeveynlerin söyledikleri aşağıda tırnak içinde aynen aktarılmıştır.

E1. “okuması gelişmesi için bol bol kitap okumasını isterim”,

E7. “daha hızlı anlaşılır bi şekilde okumasını isterim”'

E6. "benimle yemek yapmasını ve bu konuda gelişmesini çok isterim”'

E9. "el ve kol kaslarını geliştiren etkinlikler yapmasını isterim”,

Sonuç olarak; ebeveynler, çocuklarının serbest zamanlarda tv izlediğini, müzik dinlediğini, kitap okuduğunu, ödevlerini yaptığını, cep telefonuyla oynadığını, kardeşiyle oyunlar oynadığını, boyama yaptığını, deney yaptığını, kağıt kestiğini, egzersizlerini yaptığını, dans ettiğini, muhabbet kuşuyla vakit geçirdiğini, tabletle oyunlar oynadığını, dinlendiğini ve resim yaptığını belirtmişlerdir.

ÇY sahip çocuğu olan ebeveynler, çocuklarıyla yaptıkları fiziksel etkinliklere yönelik; egzersiz yaptıkları, oyun oynadıkları, bahçede vakit geçirdikleri, seyahat ettiklerini, sosyal etkinliklere yönelik; sinemaya gittikleri, arkadaşlarıyla buluştukları, yemeğe çıktıkları ve sohbet ettiklerini, yetenek gerektiren etkinliklere yönelik; resim yaptıkları, yüzmeye gittikleri, müzik dinledikleri, ahşap boyama yaptıkları, yazı yazdıkları ve dans ettiklerini, kişisel gelişim etkinliklerine yönelik ise; ödev yaptıkları, birlikte kitap okudukları, dini ibadetlerde bulundukları, şarkı söyledikleri, şiir okuduklarını ifade etmişlerdir. Bir ebeveyn ise çocuğunun ağır düzeyde bir yetersizliğinin olmamasına rağmen herhangi bir kişisel becerisinin olmadığını belirtmiştir. 
Çoklu Yetersizliğe Sahip Çocuğu Olan Ebeveynlerin Serbest Zaman Etkinliklerine

Yönelik Görüşlerinin İncelenmesi

ÇY olan öğrenciler anneleriyle; en çok ev işi yapmaktan, alışveriş yapmaktan ve seyahat etmekten hoşlanmaktadırlar. Babalarıyla; gezmek ve sohbet etmekten, kardeşleriyle ise; oyun oynamaktan ve film izlemekten hoşlanmaktadırlar. ÇY sahip çocuğu olan ebeveynler çocuklarının serbest zamanlarında en çok kitap okumasını, fiziksel hareketler yapmasını ve akademik becerilerini geliştirmesini istemektedirler.

\section{Tartışma}

ÇY olan öğrencilerin serbest zamanlarda yaptıkları etkinliklerin ebeveyn görüşlerine göre incelendiği araştırmanın bulguları incelendiğinde ebeveynler, ÇY olan çocukların ev ortamında en fazla (n:11) televizyon izleyerek vakit geçirdiğini ifade etmişlerdir. Benzer bulgulara Margalit'in $(1981,1984)$ yapmış olduğu çalışmalarda rastlamak mümkündür. Serebral palsili ve öğrenme güçlüğü olan çocukların daha çok ev ortamında zamanlarını televizyon izleyerek pasif bir şekilde geçirdikleri tespit edilmiştir. Bu açıdan incelendiğinde yapılan çalışmanın ÇY olan çocukların ev ortamında zamanlarını televizyon izleyerek geçirmesi bulgusu, Margalit'in (1981, 1984) yapmış olduğu bu çalışmanın bulgularıyla örtüşmektedir. Benzer bir bulgu da Dykens'in (2012) yapmış olduğu çalışmada göze çarpmaktadır. Dykens (2012) prader willi sendromundan etkilenen bireylerin serbest zamanlarında televizyon izlediklerini, fiziksel etkinliklere ise katılmadıklarını tespit ettiği araştırmanın bulgularıyla örtüşmektedir.

Sun, 1998 yılında yayımlamış olduğu temel müzik eğitimi kitabında okul yaşında olan çocukların ve gençlerin daha çok müzik dinledikleri, müziksel etkinliklere ve halk oyunlarına katıldıklarını belirtmiştir. Balcı'nın (2003) yapmış olduğu araştırmada öğrenciler serbest zamanlarında en çok yaptığı etkinlikleri sıralamışlar ve müzik dinleme, müzikle uğraşma etkinliğinin ikinci sırada olduğu tespit edilmiştir. Yani öğrencilerin serbest zamanlarında en sık yaptığı etkinlikler sıralamasında müzik dinlemek vardır. Yapılan araştırmada da ÇY olan çocuklar serbest zamanlarını müzik dinleyerek geçirdikleri tespit edilmiş̧ir. Yapılan iki araştırma incelendiğinde katılımcı özellikleri bakımından gelişimsel ve zihinsel özellikleri bakımından farkl11ıklar olsa da serbest zamanlarında yaptıkları etkinlikler bakımından benzerlik göstermektedir. $\mathrm{Bu}$ açıdan incelendiğinde Balcı'nın (2003) yapmış olduğu araştırmanın öğrencilerin serbest zamanlarında en çok müzik dinlediği bulgusu, yapılan araştırmanın bulgusuyla benzerlik göstermektedir. Her ne kadar gelişim özellikleri farklı olsa da müzik 
Çay \& Eratay (2019)

dinlemenin ve müzikle uğraşmanın bireyleri dinlendirdiği, sakinleştirdiği böylelikle yaşam kalitesini olumlu etkilediği söylenebilir.

Alanyazın incelendiğinde serbest zaman etkinliklerine katılmanın bireylerin yaşam kalitesi üzerinde olumlu etkileri olduğu vurgulanmaktadır. Mc Manus, Corcoran, ve Perry'nin (2008) serebral palsili çocuklarla yaptığı araştırmada serbest zaman etkinliklerine katılımın çocukların yaşam kalitesini artırdığı tespit edilmiştir. Yine benzer bir çalışmada (Bjornson, Belza, Kartin, Logsdon, McLaughlin, ve Thompson, 2008) da etkiliklere kat1lımın fiziksel ve psikososyal gelişimin üzerinde etkili olduğu vurgulanmıştır.

Büküşoğlu ve Bayturan'a (2005) göre bireylerin serbest zaman etkinliklerine katılmaları akranlarıyla iletişim kurmalarına ve etkileşimde bulunmalarına olanak sağlamaktadır. Akranlarıyla etkileşim ve iletişimde bulunan bireyler kendilerini daha rahat ve kolay bir şekilde ifade edebilirler. Akranlarla serbest zamanlarda etkinliklere katılmak bireylerin güçlü yönlerinin ortaya çıkmasını sağlar, bireylerin kendilerini tanımalarına firsat vererek ayrıca akran arasında kabul duygusunun gelişmesine de yardım etmektedir. Yapılan araştırmanın bulguları incelendiğinde ÇY olan çocuklar serbest zamanlarda sosyal etkinlikler içerisinde yer alan arkadaşlarıyla buluşmak ve sohbet etmek yer almaktadır. ÇY olan çocukların serbest zamanlarında arkadaşlarıyla bir araya gelip bir yerlere gitmesi ve arkadaşlarıyla vakit geçirmesi onlara akranlarıyla etkileşimde bulunma firsatı vereceği söylenebilir. Akranlarıyla iletişim kuran ve paylaşımda bulunan bireylerin kendilerini daha rahat ifade edeceği ve sosyal becerilerinin gelişeceği söylenebilir.

Serbest zaman etkinliklerine ebeveynlerin çocuklarıyla birlikte katılması, ÇY olan bireylerin serbest zaman etkinliklere katılımını arttıracağı söylenebilir (Bult, Verschuren, Lindeman, Jongmans, ve Ketelaar, 2013; King, Law, Hurley, Petrenchik, ve Schwellnus, 2010). Yapılan araştırmandın bulguları incelendiğinde de ÇY olan çocuklar serbest zaman etkinliklerine ebeveynleriyle birlikte katılmışlardır. ÇY olan çocukların ebeveynleriyle sinemaya, pikniğe, gezmeye gittikleri; birlikte kitap okudukları ve ev işleri yaptıkları tespit edilmiştir. Böylelikle ÇY sahip çocuğu olan ebeveynler çocuklarıyla serbest zaman etkinliklerine katılarak çocuklarına olumlu rol model oldukları; çocuklarını bu tür etkinliklere katılmaya teşvik ettikleri söylenebilir. $\mathrm{Bu}$ açıdan incelendiğinde yukarıda belirtilen görüşü destekler nitelikte olduğu görülmektedir.

Gültekin'e (2008) göre serbest zamanlarını değerlendirme bakımından cinsiyete göre farklılık olduğunu, erkeklerin kadınlara göre daha aktif etkinliklere katılarak değerlendirdiğini; 
Çoklu Yetersizliğe Sahip Çocuğu Olan Ebeveynlerin Serbest Zaman Etkinliklerine

Yönelik Görüşlerinin İncelenmesi

bayanların ise serbest zamanlarını dinlenerek, el işleri yaparak evde geçirdiklerini belirtmiştir. Yapılan araştırmanın bulguları arasında ÇY olan bireyler babalarıyla yürüyüşse giderek, parka giderek, sinemaya giderek serbest zamanlarını değerlendirirken; anneleriyle ev işi yapmak (evi temizlemek, toplamak vb.), sohbet etmek, kitap okumak, film seyretmek gibi ev içi etkinlikleri yaptıkları tespit edilmişsir. Dolayısıyla yapılan çalışmanın bu bulguları, Gültekin'in (2008) görüşüyle paralellik göstermektedir.

ÇY olan çocuklar babalarıyla serbest zamanlarda yürüyüş yapmak, doğada gezmek gibi fiziksel etkinlikler yapmaları yürütülen çalışmanın bulguları arasında yer almaktadır. Alanyazında yapılan çalışmaların (Shikako-Thomas ve diğ., 2012; Çöl, 2005) bulgularında da bireylerin fiziksel etkinliklere katılması yaşam kalitesini ve genel sağlı̆ı üzerinde olumlu etkileri olduğu tespit edilmiştir. Ayrıca Buffart, Bergemons, Meeteren, Stam, ve Roebroeck (2009) araştırmasında bir fiziksel yetersizlik türü olan ve diğer adı Spina Bifida olan myelomeningoselli adölesanların fiziksel etkinliklere katılmaları fiziksel sağlığına ve dolayısıyla yaşam kalitelerini olumlu etkilediği sonucuna ulaşmıştır. Dolayısıyla yapılan çalışmanın bulgularından yola çıkarak yürüyüş yapmak, spor yapmak gibi fiziksel etkinliklere katılım ÇY olan çocukların fiziksel ve psikolojik sağlığı üzerinde etkili olduğu; hem ruhsal hem de fiziksel olarak sağlıklı bireyler olmalarının yanı sıra serbest zamanlarını kaliteli bir şekilde geçirmelerini sağladığı söylenebilir.

Larson ve Seepersad'ın (2003) ergen bireylerle yaptığı çalışmada yaş ergenlerin entelektüel ve fiziksel etkinliklere daha az katıldıkları, sosyal etkinliklere ise daha çok katıldıklarını ve daha fazla vakit ayırdıklarını tespit etmiştir. Yapılan araştırmada ise; 15-18 yaş arasında ÇY olan çocuklar fiziksel, sosyal, kişisel gelişim sağlayan etkinlikler ve yetenek gerektiren etkinlikleri yapmada yaş farkının etkili olmadığı; 15-18 yaş aralığında ÇY olan çocukların bu tür etkinliklere katıldıkları tespit edilmiştir. Bu açıdan değerlendirildiğinde Larson ve Seepersad'ın (2003) yapmış olduğu araştırma bulgusuyla örtüşmediği görülmektedir.

Eldeniz Çetin ve Terzioğlu (2018) yapmış oldukları çalışmada ağır düzeyde yetersizliğe sahip çocukların serbest zamanlarını en çok anne ve babalarıyla geçirdiklerini tespit etmişlerdir. Ağır düzeyde yetersizliğe sahip bireylerin yaşamın her alanında ebeveynlerinin desteğine ihtiyaç duydukları için araştırma bulgularında serbest zamanlarını aileleriyle geçirdikleri tespit edilmiştir. Yapılan araştırmaya katılan ebeveynlerin çocukları hafif düzeyde ÇY'den etkilenmiş olmasına rağmen yapılan araştırmanın bulgularında da benzer sonuçlar elde edilmiş̧ir. ÇY olan 
Çay \& Eratay (2019)

çocuklar serbest zamanlarını değerlendirmek için serbest zaman etkinliklerini anne ve babalarıyla gerçekleştirdikleri bulgusu Eldeniz Çetin ve Terzioğlu'nun (2018) yapmış olduğu çalışma bulgularıyla paralellik göstermektedir. ÇY olan çocukların ebeveynleriyle zaman geçirmeleri geçirdikleri serbest zamanlarını daha kaliteli ve verimli yapacağı; ÇY olan çocukların ebeveynleriyle olan aile bağlarını daha da güçlendireceği söylenebilir.

\section{Sonuç ve Öneriler}

Araştırma sonucunda; ÇY olan öğrencilerin evde serbest zamanlarında daha çok televizyon izledikleri, kitap okudukları, müzik dinledikleri ve cep telefonuyla oynadıkları tespit edilmiştir. Ebeveynler, evde serbest zamanlarda çocuklarıyla egzersiz yaptıklarını, oyun oynadıklarını, sinemaya ve yemeğe gittiklerini; sohbet ettiklerini, birlikte kitap okuduklarını, dini ibadetlerde bulunduklarını ve seyahat ettiklerini ifade etmişlerdir.

$\mathrm{Bu}$ araştırma; Nitel bir araştırma olması nedeniyle bu çalışmadan elde edilen sonuçlar genellenememekle birlikte, araştırmaya katılan 15 ebeveynin görüşü ile, araştırma yöntemlerinden nitel araştırma ve veri toplama tekniklerinden görüşme tekniği ile sınırlı olmakla birlikte aşağıdaki önerilerde bulunulabilir.

ÇY olan bireylere serbest zamanlarını daha kaliteli geçirebilmeleri için serbest zaman eğitimi verilebilir.

ÇY sahip çocuğu olan ebeveynlere serbest zaman etkinliklerine yönelik eğitim verilebilir.

ÇY olan çocukların daha kaliteli ve verimli bir şekilde serbest zamanlarını geçirebilmeleri için öğretmen veli işbirliği önerilebilir.

Ailelerin serbest zamanlarını değerlendirmeleri, çocuklarıyla sosyal ortamlarda vakit geçirmelerini sağlayacak maddi olanaklar yetkililer tarafından ÇY olan çocuk ailelerine sağlanabilir.

\section{Kaynakça}

Akyıldız, M. (2013). Boş zamana "ciddi” bir bakış: Boş zaman araştırmalarında ciddi boş zaman teorisi. Pamukkale Journal Of Sport Sciences, 4(2), 46-59. 
Çoklu Yetersizliğe Sahip Çocuğu Olan Ebeveynlerin Serbest Zaman Etkinliklerine Yönelik Görüşlerinin İncelenmesi

Akandere, M., Acar, M., \& Baştuğ, G. (2009). Zihinsel ve fiziksel engelli çocuğa sahip anne ve babaların yaşam doyumu ve umutsuzluk düzeylerinin incelenmesi. Selçuk Üniversitesi Sosyal Bilimler Enstitüsü Dergisi, (22).

Badia, M., Orgaz, M.B, Verdugo, M.A, Ullán, A, \& Martinez, M. (2013). Relationships between leisure participation and quality of life of people with developmental disabilities. Journal of Applied Research in Intellectual Disabilities, 26 (6), 533-545.

Balcı, V. (2003), Ankara'daki üniversite öğrencilerinin bos zaman etkinliklerine katılımlarının araştırılması. Milli Egitim Dergisi, 158(1), 161-173.

Bayram, E. (2016). Zihinsel yetersizliği olan ve olmayan ergenlerin boş zamanların değerlendirme biçimleri, (Yüksek Lisans Tezi), Abant İzzet Baysal Üniversitesi Eğitim Bilimleri Enstitüsü Özel Eğitim Anabilim Dalı Zihin Engellilerin Eğitimi Bilim Dalı, Bolu.

Bahçıvancıoğlu-Yazıcı, A. \& Akçin, N. (2014). Çoklu yetersizliği olan çocukların annelerinin çocuklarının gelişimlerine ilişkin görüşlerinin betimlenmesi. Ahi Evran Üniversitesi Kırşsehir Eğitim Fakültesi Dergisi (KEFAD) 15(2), 335-356.

Bult, M. K., Verschuren, O., Lindeman, E., Jongmans, M. J., \& Ketelaar, M. (2013). Do children participate in the activities they prefer? A comparison of children and youth with and without physical disabilities. Clinical rehabilitation, 28(4), 388-396.

Buffart, L. M., Bergemons, R. J. V. D., Meeteren, J. V., Stam, H. J., \& Roebroeck, M. E. (2009). Lifestyle, participation, and health-related quality of life in adolescents and young adults with myelomeningocele. Developmental Medicine and Child Neurology, 51(11), 886-894

Büküşoğlu, N. \& Bayturan, A.F. (2005). Serbest zaman etkinliklerinin gençlerin psiko-sosyal durumlarına ilişkin algısı üzerindeki rolü. Ege Tip Dergisi, 44(3), 173-177.

Bjornson, K. F., Belza, B., Kartin, D., Logsdon, R., McLaughlin, J., \& Thompson, E. A. (2008). The relationship of physical activity to health status and quality of life in cerebral palsy. Pediatric physical therapy: the official publication of the Section on Pediatrics of the American Physical Therapy Association, 20(3), 247.

Clark, A., \& Percy-Smith, B, (2006). Beyond consultation: Participatory practices in everyday spaces. Children, Youth and Environments, 16 (2). 1-9. 
Çay \& Eratay (2019)

Cohen-Gewerc, E., \& Stebbins, R. A. (2007). The idea of leisure. In E. Cohen-Gewerc \& R. A. Stebbins (Eds.), The pivotal role of leisure education: Finding personal fulfillment in this century (pp. 1-14). Pennsylvania: Venture Publishing, Inc.

Csikszentmihalyi, M. (2000). Beyond boredom and anxiety. Jossey-Bass. (Original work published in 1975)

Devine, M. A. (2016). Leisure-time physical activity: Experiences of college students with disabilities. Adapted Physical Activity Quarterly, 33(2), 176-194. doi:10.1123/APAQ.20140241

Dykens, E. M. (2012). Leisure activities in prader-wlli syndrome: Implications for health, cognition and adaptive functioning, Journal of Autism and Developmental Disorders, 44(2), doi 10.1007/s10803-012-1462-7

Engel-Yeger B, Jarus T, Anaby D, \& Law M. (2009). Differences in patterns of participation between youths with cerebral palsy and typically developing peers. Am J Occup Ther. 63, 96-104.

Eriksson L, Welander J, \& Granlund M. (2007). Participation in everyday school activities for children with and without disabilities. J Dev Phys Disabil, 19, 485-502.

Eratay, E. (2013). Effectiveness of leisure time activities program on social skills and behavioral problems in individuals with intellectual disabilities. Department of Special Education, Full Length Research Paper, doi: 10.5897

Eratay, E. \& Aydoğan, Y. (2015). Study of the relationship between leisure time activities and students of Abant İzzet Baysal University levels of assertiveness. Procedia - Social and Behavioral Sciences 191. 2213

Eldeniz Çetin, M. (2013). Ağır ve çoklu yetersizliği olan bireylerin tercihlerinin değerlendirilmesi ve seçim yapma becerisinin öğretimi (Yayımlanmamış doktora tezi, Gazi Üniversitesi, Eğitim Bilimleri Enstitüsü, Ankara, Türkiye). http://tez.yok.gov.tr/UlusalTezMerkezi/' inden elde edilmiştir. (Tez No. 333504)

Eldeniz Çetin, M. \& Çay, E. (2017). Zihinsel yetersizliği olan öğrencilerin boş zaman becerilerine ilişkin öğretmen görüşlerinin belirlenmesi, Kesit Akademi Dergisi, 3(10), $732-755$. 
Çoklu Yetersizliğe Sahip Çocuğu Olan Ebeveynlerin Serbest Zaman Etkinliklerine Yönelik Görüşlerinin İncelenmesi

Eldeniz Çetin, M. \& Terzioğlu, N.K. (2018). Ağır düzeyde yetersizliğe sahip çocuğu olan annelerin çocuklarının boş zamanlarını değerlendirmeye yönelik görüşleri. Abant İzzet Baysal Üniversitesi Eğitim Fakültesi Dergisi, 18 (2), 857-873.

Gültekin, E. (2008). Serbest zaman etkinlikleri içinde müzikli etkinliklerin yeri: Sakarya mahallesi örneği, (Yayınlanmış yüksek lisans tezi). Sakarya Üniversitesi Sosyal Bilimler Enstitüsü. Sakarya

Güngörmüss, H. A. (2007). Özel sağllk-spor merkezlerinden hizmet alan bireyleri rekreasyonel egzersize güdüleyen faktörler. (Yayımlanmamıș doktora tezi). Gazi Üniversitesi, Ankara.

Gümüş, H. Işık, Ö., Karakullukçu, Ö., Yıldırım, İ. (2016).Ortaöğretim Kurumlarında Serbest Zaman Fiziksel Aktivite Kistllayıc1ları. International Journal of Sport Culture and Science, 2 (Special Issue 1), 814-825. DOI: 10.14486/IJSCS152

Gilson, C. L., \& Dymond, S. K. (2011). Constructions of disability at a university in Hong Kong: Perspectives of disabled students, staff members, and instructors. Disability Studies Quarterly. 31(2) Retrieved May 16, 2011 from http://www.dsq-sds. org/article/view/1589/1557

Hacıoğlu N, Gökdeniz A, \& Dinç Y. (2003). Boş zaman-rekreasyon yönetimi. Detay Yayıncılık, I.Bask1, Ankara. A Sequence Aligment Method. Annals of Tourism Reserch, 29.

Jessup, G. M., Cornell, E., \& Bundy, A. C. (2010). The treasure in leisure activities: Fostering resilience in young people who are blind. Journal of Visual Impairment \& Blindness, 104(7), 419-430.

King, G., Law, M., Hurley, P., Petrenchik, T., \& Schwellnus, H. (2010). A developmental comparison of the out-of-school recreation and leisure activity participation of boys and girls with and without physical disabilities. International Journal of Disability, Development and Education, 57(1), 77-107.

Kim J, Lee S, Chun S, Heo J, \& Han A. (2014). Contribution of leisure-time physical activity on psychological benefits among elderly immigrants. Applied Research in Quality of Life. 11(2):461-

Lambe, L. \& Mount, H. (2013). Holidays and outings. In J. Hogg \& J Cavet (eds.), Making leisure provision for people with profound learning and multiple disabilities. Springer. 
Çay \& Eratay (2019)

Larson, R. \& Seepersad, S. (2003). Adolescents' leisure time in the united states: Partying, sports, and the American experiment. New Directionss For Child and Adolescent Development, 99(1), 53-64, doi: $\underline{10.1002 / \mathrm{cd} .66}$

Leitner, M. J., \& Leitner, S. F. (2012). Concepts of leisure. Leisure enhancement, 4th ed. Urbana, IL: Sagamore Publishing LLC.

Leach, M. \& Bailey, H. (2013). Physical activities. In J. Hogg \& J Cavet (eds.), Making leisure provision for people with profound learning and multiple disabilities. Springer.

Lundberg, N. R., Taniguchi, S., McCormick, B. P., \& Tibbs, C. (2011). Identity negotiating: Redefining stigmatized identities through adaptive sports and recreation participation among individuals with a disability. Journal of Leisure Research, 43(2), 205-225.

Mansell, J. (2010). Rasing our sights: Services for adults with profound intellectual and multiple disabilities. www.dh.gov.uk/en/Publicationsandstatistics.

Margalit, M. (1984). Leisure activities of learning disabled children as a reflection of their passive life style and prolonged dependency. Child psychiatry and human development, 15(2), 133-141.

Margalit, M. (1981). Leisure activities of cerebral palsied children. Israel journal of psychiatry and related sciences. 18(3), 209-214.

Mount, H. (2013). Art, drama and music. In J. Hogg \& J Cavet (eds.), Making leisure provision for people with profound learning and multiple disabilities. Springer.

Mc Manus, V., Corcoran, P., \& Perry, I. J. (2008). Participation in everyday activities and quality of life in pre-teenage children living with cerebral palsy in South West Ireland. BMC pediatrics, 8(1), 50. doi:10.1186/1471-2431-8-50

Müderrisoğlu, H., Kutay, E.L., \& Örnekçi Eşen, S., 2006. Kırsal rekreasyonel faaliyetlerde kisıtlayıc1lar, Tarım Bilimleri Dergisi 2005, 11 (1) 40-44.

Ouvry, C. \& Mitchell, S. (2013). Play materials. In J. Hogg \& J Cavet (eds.), Making leisure provision for people with profound learning and multiple disabilities. Springer.

Porter, H., Iwasaki, Y., \& Shank, J. (2010). Conceptualizing meaning-making through leisure experiences. Loisir Et Société /Society and Leisure, 33(2), 167-194. doi:10.1080/07053436.2010.10707808 
Çoklu Yetersizliğe Sahip Çocuğu Olan Ebeveynlerin Serbest Zaman Etkinliklerine Yönelik Görüşlerinin İncelenmesi

Sardohan-Yıldırım, A. E. \& Akçamete, G. (2014). Çoklu yetersizliği olan çocuğa sahip annelerin erken çocukluk özel eğitimi hizmetleri sürecinde karşılaştıkları güçlüklerin belirlenmesi. Cumhuriyet International Journal of Education-CIJE, 3 (1), 74-89. ISSN: 2147-1

Sivan, A., \& Ruskin, H. (2000). Leisure education, community development and populations with special needs. Wallingford, GB: CAB International. Retrieved from http://www.ebrary.com.

Spevack, S., Martin, T. L., Heibert, R., Yu, C. T. \& Martin, G. L. (2004). Effects of choice of work tasks on on-task, aberrant, happiness and unhappiness behaviors of persons with developmental disabilities. Journal on Developmental Disabilities, 11(2), 79-97.

Schulz, J. \& Watkins, M. (2007). The development of the leisure meanings inventory. Journal of Leisure Research, 39(3), 477.

Stebbins, R. A. (2005). Project based leisure: theoretical neglect of a common use of free time. Leisure Studies, 24(1), 1-11.

Shikako-Thomas, K., Dahan-Oliel, N., Shevell, M., Law, M., Birnbaum, R., Rosenbaum, P., \& Majnemer, A. (2012). Play and be happy? Leisure participation and quality of life in school-aged children with cerebral palsy. International journal of pediatrics, 1-7 doi:10.1155/2012/387280

Solish, A., Perry A, \& Minnes P. (2010). Participation of Children with and without Disabilities in Social, Recreational and Leisure Activities. Journal of Applied Research in Intellectual Disabilities 23 (3), 226-236.

Sun, M. (1998). Temel müzik egitimi, Ankara: Yurt Renkleri Yayınevi

Şafak, P. (2012). Ağır ve çoklu yetersizliği olan çocukların eğitimi Ankara: Vize yayıncılık.

Safak, P., \& Uyar, D., (2015).Teaching choice making to children with severe and multiple disabilities.Turkish Studies. International Periodical for the Languages, Literature and History of Turkish or Turkic, 10(3), 779-798. doi: 10.7827/TurkishStudies.7726

Trainor, S., Delfabbro, P., Anderson, S. \& Winefield, A. ( 2009). Leisure activities and adolescent psychological well being. Journal of Adolescence,3(3), 8-13.

Wehmeyer, M. L. (2003). Self-determination, vocational rehabilitation and workplace supports. Journal of Vocational Rehabilitation, 19, 67-69. 
Çay \& Eratay (2019)

World Health Organization (Ed.). (2001). International classification of functioning, disability, and health: Children and youth version: ICF-CY. World Health Organization. 